\title{
SQUAMOUS CELL CARCINOMA IN OVINES IN THE STATE OF ACRE ${ }^{1}$
}

\author{
EDUARDO MITKE BRANDÃO REIS ${ }^{2}$, RENAN DE MELLO SPADETTO ${ }^{3}$, SARA LUCENA DE AMORIM ${ }^{2}$, \\ GRAZIELA BARIONI ${ }^{3}$, FELIPE BERBARI NETO ${ }^{3 *}$
}

\begin{abstract}
The squamous cells carcinoma (SCC), also known as epidermoid carcinoma, is a malign neoplasia of the squamous layer of the skin's epidermis, very common in bovines of tropical countries such as Brazil, due to the chronic exposure of animals to ultraviolet radiation. The objective of this work was to describe SCC cases in sheep (Ovis aries), because it is known that this disease is rare in this species. A standard animal of approximately six years old was assisted in the municipality of Rio Branco, State of Acre, in Brazil, presenting cachectic state and multifocal tumors. Despite the rarity of this neoplasia in sheep, it is important to use preventive measures, such as: avoiding acquisition of depigmented animals, with absent or sparse fur coverage and, mainly avoiding prolonged exposure to ultraviolet lights, which could cause the appearance of this morbid disease.
\end{abstract}

Keywords: Epidermis. Epidermoid. Neoplasia. Ovis aries.

\section{CARCINOMA DE CÉLULAS ESCAMOSAS EM OVINO NO ESTADO DO ACRE}

RESUMO - O carcinoma de células escamosas (CCE), também conhecido como carcinoma epidermoide, é uma neoplasia maligna da camada escamosa da epiderme da pele, muito comum em bovinos de países tropicais como o Brasil, devido à exposição crônica dos animais à radiação ultravioleta. Objetivou-se com este trabalho descrever caso de CCE em ovino, pois, sabe-se que a doença é rara nesta espécie. O animal SRD, de aproximadamente seis anos de idade, foi atendido no município de Rio Branco, estado do Acre, apresentando estado caquético e tumorações multifocais. Apesar desta neoplasia ser rara em ovinos, é importante fazer uso de medidas de prevenção como: evitar adquirir animais despigmentados, com cobertura de pelos ausentes ou esparsas e principalmente, evitar exposição prolongada à luz ultravioleta, podendo ter como ônus o surgimento desse tipo de processo mórbido.

Palavras-chave: Carcinoma epidermoide. Carneiro. Patologia.

\footnotetext{
*Corresponding author

${ }^{1}$ Received for publication in $05 / 25 / 2015$; accepted in 09/23/2015.

${ }^{2}$ Center of Biological Sciences and Nature, Universidade Federal do Acre, Rio Branco, AC, Brazil; edumitke@hotmail.com, saravet.la@bol.com.br.

${ }^{3}$ Center of Agricultural Sciences, Department of Veterinary Medicine, Universidade Federal do Espírito Santo, Alegre, ES, Brazil; renanspadeto@hotmail.com,grazibari@gmail.com, berbarineto@hotmail.com.
} 


\section{INTRODUCTION}

In the last few years, sheep raising has presented a high growth in the State of Acre (AC), with introduction of improved animals by the State Government, which were distributed to family based rural producers, however, in this equatorial region, where the ultraviolet ray incidence is high, a predisposition to skin lesions in these animals may occur. The squamous cells carcinoma (SCC), also known as epidermoid carcinoma, is a malign neoplasia of the squamous layer of the skin's epidermis, very common in bovines from tropical countries such as Brazil, due to the chronic exposure of the animals to ultraviolet radiation. The development of these kind of tumors is associated with many other factors, including the lack of epidermis pigmentation, fur loss and sparse fur coverage in the affected locations (Ramos e $t$ al., 2007). According to Meuten (2002), the incidence may increase with age.

The biological behavior of the SCC is locally invasive, destructive and proliferative, but generally with low metastatic potential. In the initial phase, the SCC clinical symptoms are characterized by erythematous lesions associated with cutaneous edemas, alopecia, scaling, thickening and ulceration (Meuten,2002).

The diagnosis and the clinical staging of a neoplasia are essential to the selection of an adequate therapeutic modality for oncological patients, and are grounded in laboratory exams (blood count, urinalysis, serum biochemistry) for diagnosis through images (X-ray, ultrasound, computed tomography, magnetic resonance imaging) and pathological exams (cytopathology, histopathology and immunohistochemistry). A careful clinical exam is also fundamental to the evaluation of all oncological patients (Andrade, 2002).

The objective of this work was to describe the clinic findings observed in sheep raising with history of tumors and cachexy, and the histopathological findings in an ovine with generalized lesions of SCC, in the State of Acre, as well as remind fundamental aspects of this illness, discussing determinant factors for this disease.

\section{MATERIAL AND METHODS}

A sheep of approximately six years old with no definitive breed, was assisted in the Federal University of Acre, municipality of Rio Branco, AC, Brazil. The animal was in a cachectic state, presenting multifocal tumors. The presence of tumors in the animal's skin was observed in the physical exam. The abnormalities were located on the back area, near the right shoulder blade, in the external ear and the back of the belly region. The tumors presented firm consistency and, macroscopically, an "cauliflower" aspect, with little fur and no pigmentation, erythema, edema and scaling, followed by formation of crusts and thinning of the skin with subsequent ulceration. There were also present signs of secondary infections and myiasis (Figure 1).

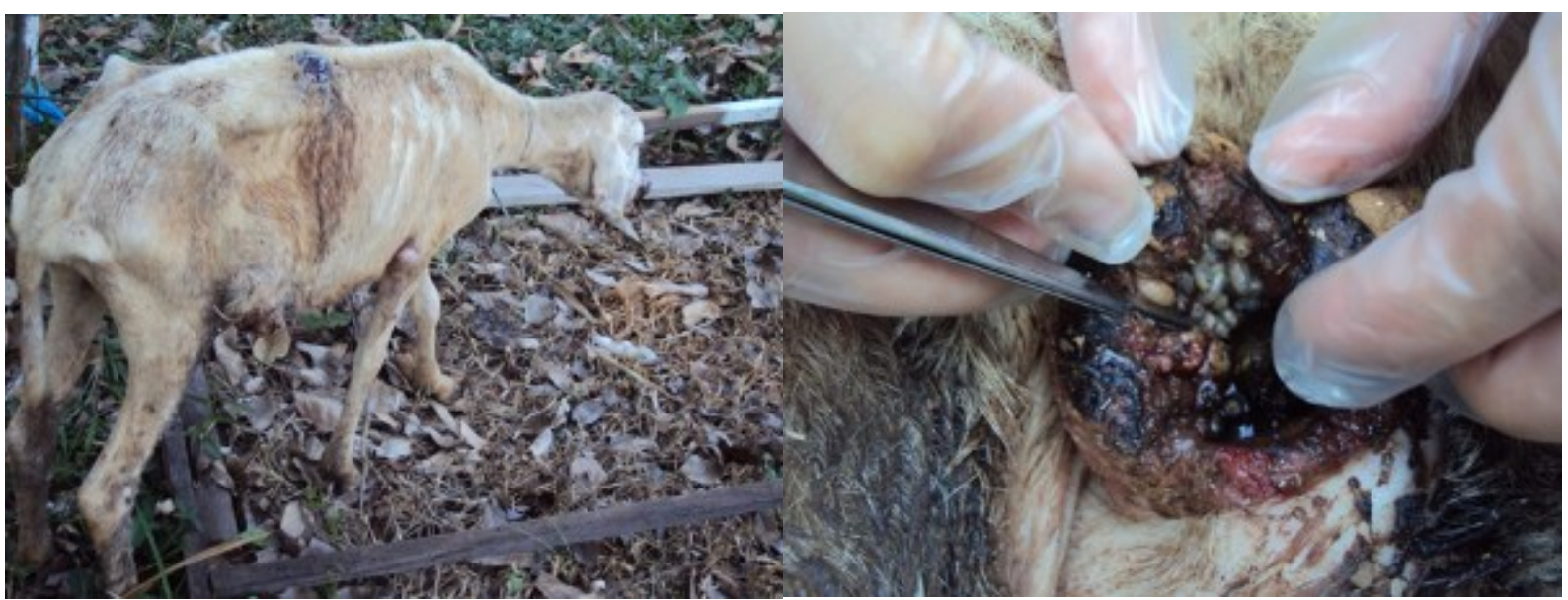

Figure 1. Ovine presenting multifocal tumors, suggesting SCC, with fly larvae in the skin tumor ulceration.

The euthanasia was performed with Thiopental Sodium (12.5 mg kg $\mathrm{mg}^{-1}$ intravenously) followed by potassium chloride (4 $\mathrm{mg} \mathrm{kg}^{-1}$ intravenously). Tumor lesions restricted to the skin without evidence of visceral metastasis were observed in the autopsy. The mucous membranes were pale and there was presence of a translucent fluid in the pericardial sac, low blood viscosity and endo-parasites in the abomasum region. The tumors were collected and packed in glass containers containing water with $10 \%$ of formalin. After identification, the containers were sent to the Laboratory of Histopathology of the Federal University of Campina Grande, Patos Campus, for confirmation of the suspected diagnosis. Additionally, clinical and epidemiological data were obtained in a visit to the property with the farmer. 


\section{RESULTS AND DISCUSSION}

The farmer reported similar problems (presence of tumors and progressive weight loss) in four other sheep, which eventually died, from a herd of 13 animals, 12 females and a lamb. All animals were under the same environment, with scarce shading and with no technical assistance. The clinical exam of seven other sheep and the lamb did not present noticeable alterations. The material sent to the laboratory confirmed the SCC diagnosis, characterized by skin with tumor mass formed by the proliferation of squamous cells from a round/oval nucleus, with an evident nucleolus, although doubled, fragmented chromatin and eosinophilic, abundant cytoplasm, forming invasive nests and cords in the dermis (Figure 2A).

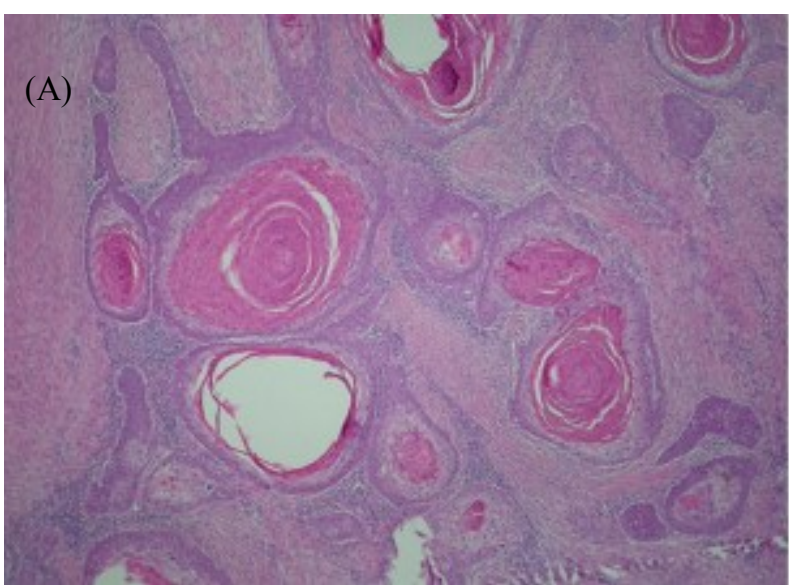

There was also a grouping of neoplastic cells presenting keratinization of the center, mitotic figures of a 12 per $40 \mathrm{X}$ field, bizarre cells and pleomorphism of the core. There was proliferation of fibroblasts in the dermis and focal area of the necrosis in the epidermis (ulcer), with predominantly neutrophilic infiltration, basophilic granules (bacteria) and hemorrhage - Secondary lesions (Figure 2B). Metastasis was found in lymph node, confirming the malignant nature of the neoplasm.

The squamous cell carcinoma is a malignant neoplasia of epidermal cells that differentiates and change to parakeratosis. These neoplastic squamous cell are not confined to the outer surface of the neoplasm, irregular masses and elongated strands of the neoplastic cells may extend randomly throughout the underlying dermal area (Jones et al, 1997).

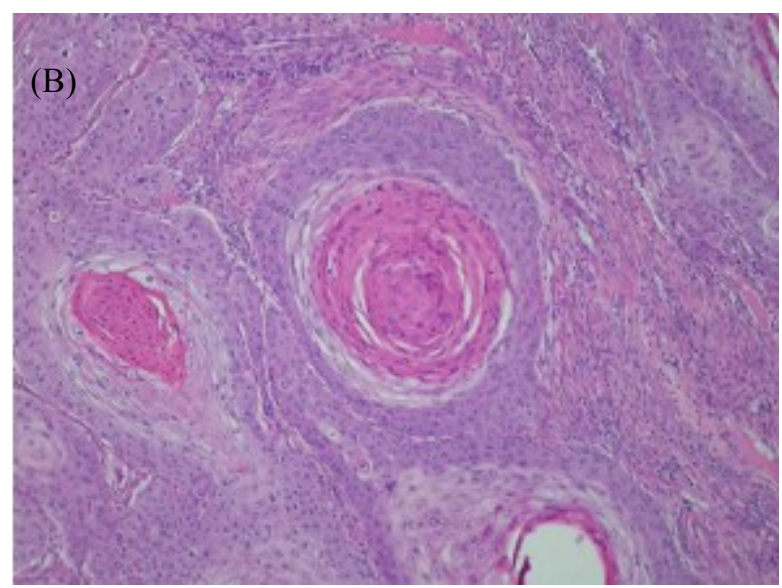

Figure 2. (A) Tumoral mass formed by squamous cells from a round/oval nucleus, with an evident nucleolus, although doubled, fragmented chromatin and eosinophilic, abundant cytoplasm, forming invasive nests and cords in the dermis. (B) Proliferation of fibroblasts in the dermis and focal area of the necrosis in the epidermis (ulcer) with predominantly neutrophilic infiltration, basophilic granules (bacteria), with secondary lesions. HE, obj 40x.

SCC usually present slow, locally invasive and not necessarily metastatic growth. It is common in canines, felines, bovines and equines, however, relatively uncommon in ovine and rare in caprine and porcine (Meuten, 2002). The low occurrence of this type of tumor in porcine and ovine, is probably due to the fact that these animals are slaughtered before reaching their middle age, which lowers their probability to develop neoplasms (Misdorp, 1990). However, in the breeding of array sheep in an equatorial climate, it was possible to observe the appearance of this neoplasm.

Regarding the injuries, they were aggravated with secondary bacterial infections and myiasis, resulting in a purulent exudate on the surface of the tumor mass (Goldschmidt and Hendrick 2002). When the tumor was cut, it had a granular aspect, whitish or yellowish and, in the histopathological examination, the lesion was characterized by epidermal proliferation, hyperkeratosis, parakeratosis, acanthosis, dysplasia and keratinocyte proliferation (Goldschmidt and Hendrick, 2002) and extending through the dermis, with or without proliferation and thickening of the epidermis with the formation of islands, and trabecular strands of neoplastic epithelial cells, with varying levels of squamous differentiation (Weiss and Mills, 1974). The individual tumor cells are big, ovoid and often containing vesicular nucleus with one central and prominent nucleoli; their abundant cytoplasm varies from pale to bright eosinophilic and the edges of the cells are evident (Goldschmidt and Hendrick, 2002).

Oliveira et al. (2011) reported that the vulva is often affected due to exposure of the skin to ultraviolet light, since this region is not pigmented and does not have fur protection. Macedo et al. (2008) also reported, in several cases, in the Brazilian semiarid region, that $80 \%$ of injuries occurred in regions with no fur and mostly in white skinned animals, suggesting that the high incidence of solar radiation in depigmented or hairless areas is an important factor.

Sheep submitted to the Mules operation (excessive or radical section of the tail) have a more exposed vulva to sun rays and greater incidence of tumors in this area (Mcgavin e Zachary 2007), 
despite the ears of this species being the most affected site, according to reports. The sun exposure, to which the animals were submitted, according to Ramos et al. (2007) and Macedo et al. (2008), should be considered a determining factor for being involved with this property, since the proximity of the region to the equator line and the lack of adequate shading in the property.

According to Scopel et al. (2007), in general, regardless of species, the females are more affected than the males, and older animals have greater predisposition to the development of squamous cell carcinoma than the younger ones (Riet Correa et al., 1981).

In the present work, the producer had 12 ewes and a lamb for lamb production, which were sold for slaughter. All his animals presented signs of being in their middle age (about six years old) and, therefore, more susceptible to SCC.

The squamous cell carcinoma is one of the few cancers with multiple treatment options, aside from surgery (Meuten, 2002). According to Ferreira et al. (2006), other options are: cryosurgery (indicated for superficial and noninvasive neoplasms), chemotherapy and photodynamic therapy. In a recent project, Cunha et al (2014) also mentioned radiotherapy. The treatment modality choice should be according to the tumor staging, the general condition of the patient, the cooperation of the owner and the availability of equipment and drugs. The precocity of diagnosis has fundamental effect on the prognosis.

As preventive measures, it is important to avoid acquiring or breeding depigmented animals, with missing or scattered fur coverage, and especially to avoid prolonged exposure to ultraviolet light, emphasizing the use of shading in the property.

\section{CONCLUSION}

The squamous cell carcinoma has a simple diagnosis in terms of elaboration, however, its prognostic is unfavorable. Despite uncommon in ovine, it is important to use prophylactic measures through technical clogging in order to avoid losses with this sort of morbid process, primarily in ewes on places that suffer excessive sun exposure.

\section{REFERENCES}

ANDRADE, S. F. Terapêutica Antineoplásica. In: ANDRADE, S. F. (Ed.) Manual de Terapêutica Veterinária. 2. ed. São Paulo: Editora Roca, 2002. Cap. 11, p. 180-197.

CUNHA, S. C. S. et al. A utilização da radioterapia no tratamento do carcinoma de células escamosas cutâneo felino avançado. Arquivo Brasileiro de Medicina Veterinária e Zootecnia, Belo Horizonte, v. 66, n. 1, p. $7-14,2014$

FERREIRA， I; RAHAL， S. C.; FERREIRA，J; CORRÊA, T. P.; Terapêutica no carcinoma de células escamosas cutâneo em gatos. Ciência Rural, Santa Maria, v. 36, n. 3, p. 1027-1033, 2006.

GOLDSCHMIDT M. H.; HENDRICK M. J. Tumors of the skin and soft tissues. In: MEUTEN D. J. (Ed.), Tumors in Domestic Animals. $4^{\mathrm{a}}$ ed. Ames: Iowa State Press, 2002. Cap. 2, p. 45-118.

JONES, T. C. et al. PatologiaVeterinária. $6^{\mathrm{a}}$ ed. Barueri, SP: Manole. 1997. 1415 p.

MACÊDO, J. T. S. A. et al. Doenças da pele em ovinos e caprinos no semi-árido brasileiro. Pesquisa Veterinária Brasileira, Rio de Janeiro, v. 28, n. 12, p. 633-642. 2008 .

MCGAVIN, M. D.; ZACHARY, J. F. Pathologic basis of veterinary disease. 4 . ed. St Louis: Mosby Elsevier, 2007. 1476 p.

MEUTEN, D. J. Tumors in Domestic Animals. $4^{\text {a }}$ ed. Ames: Iowa State Press, 2002.

MISDORP, W. General considerations, In: MOULTON J.E. (Ed.), Tumors in Domestic Animals. 3. ed. Berkeley: University of California Press, 1990. Cap. 01, p. 1-22.

OLIVEIRA-FILHO, J. P. et al. Squamous cell carcinoma in vaginal fundus in a Brahman cow. Arquivo Brasileiro de Medicina Veterinária e Zootecnia, Belho Horizonte, v. 63, n. 3, p. 749-752, 2011.

RAMOS, A.T. et al. Carcinoma de células escamosas em bovinos, ovinos e equinos: estudo de 50 casos no sul do Rio Grande do Sul. Brazilian Journal of Veterinary Research and Animal Science, São Paulo, v. 44, supl., p. 5-13. 2007.

RIET-CORREA, F. et al. Carcinomas epidermoides em ovinos em um estabelecimento do Rio Grande do Sul. Pesquisa Veterinária Brasileira, Rio de Janeiro, v. 1, n. 2, p. 65-68. 1981.

SCOPEL D.; SPADER, M. B.; GUIM, T. N.; DANIELI, V. M.; FERNANDES, C. G. Estudo retrospectivo da casuística de carcinoma de células escamosas em felinos, bovinos, caninos, equinos e ovinos entre os anos de 2002 e 2006 no LRD/ UFPEL. In: CONGRESSO DE INICIAÇÃO CIENTIFICA e ENCONTRO DE PÓSGRADUAÇÃO, 16, 2007, Pelotas, Anais..., Pelotas: UFPEL, 2007. CD-ROM. 
WEISS, E.; FRESE, K. International Histological Classification of Tumors of Domestic Animals:

Tumors of the skin. Bulletin of the World Health

Organization, Geneva v. 50, n.1, p. 79-100, 1974. 